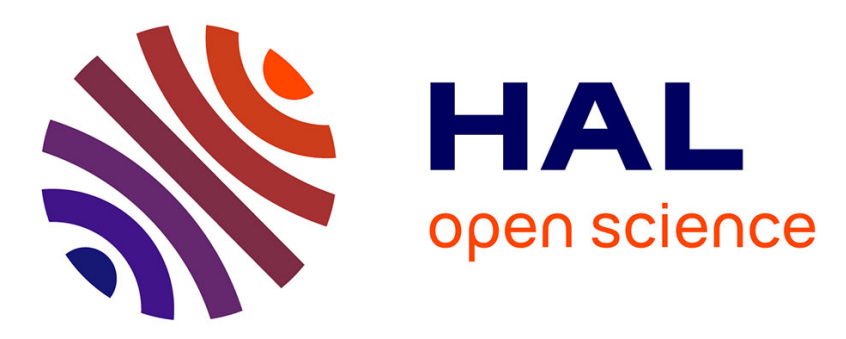

\title{
New Scandium Platinum Silicides: ScPt2Si with 'Inverse' MgCuAl2 Structure, and Sc5Pt9Si7, a Variant of the Zr2Fe12P7-Type
}

Walter Jung

\section{- To cite this version:}

Walter Jung. New Scandium Platinum Silicides: ScPt2Si with 'Inverse' MgCuAl2 Structure, and Sc5Pt9Si7, a Variant of the Zr2Fe12P7-Type. Journal of Inorganic and General Chemistry / Zeitschrift für anorganische und allgemeine Chemie, 2009, 635 (6-7), pp.920. 10.1002/zaac.200900101 . hal00484136

\section{HAL Id: hal-00484136 https://hal.science/hal-00484136}

Submitted on 18 May 2010

HAL is a multi-disciplinary open access archive for the deposit and dissemination of scientific research documents, whether they are published or not. The documents may come from teaching and research institutions in France or abroad, or from public or private research centers.
L'archive ouverte pluridisciplinaire HAL, est destinée au dépôt et à la diffusion de documents scientifiques de niveau recherche, publiés ou non, émanant des établissements d'enseignement et de recherche français ou étrangers, des laboratoires publics ou privés. 
New Scandium Platinum Silicides:

ScPt2Si with 'Inverse' MgCuAl2 Structure, and Sc5Pt9Si7, a Variant of the Zr2Fe12P7-Type

\begin{tabular}{|r|l|}
\hline Journal: & Zeitschrift für Anorganische und Allgemeine Chemie \\
\hline Manuscript ID: & zaac.200900101 \\
\hline Wiley - Manuscript type: & Article \\
\hline Date Submitted by the \\
Author: & 10-Feb-2009 \\
\hline Complete List of Authors: & Jung, Walter \\
\hline Keywords: & scandium platinum silicide , crystal structure \\
\hline
\end{tabular}

$\checkmark s$ sanhscripor central 
DOI: 10.1002/zaac.200((will be filled in by the editorial staff))

\title{
New Scandium Platinum Silicides:
}

\section{$\mathrm{ScPt}_{2} \mathrm{Si}$ with 'Inverse' $\mathrm{MgCuAl}_{2}$ Structure, and $\mathrm{Sc}_{5} \mathrm{Pt}_{9} \mathrm{Si}_{7}$, a Variant of the $\mathrm{Zr}_{2} \mathrm{Fe}_{12} \mathbf{P}_{7}$-Type}

\author{
Peter Lorenz and Walter Jung* \\ Dedicated to Professor Gerd Meyer on the Occasion of his $60^{\text {th }}$ Birthday
}

Keywords: scandium platinum silicide; crystal structure

\begin{abstract}
Two new scandium platinum silicides, $\mathrm{ScPt}_{2} \mathrm{Si}$ 'nthorhombic, Cmcm, $a=3.6653(6) \AA, b=9.831(1) \AA \AA$ . $57(1) \AA, Z=4$ ) and $\mathrm{Sc}_{5} \mathrm{Pt}_{9} \mathrm{Si}_{7}$ (hexagonal, $P \overline{6}, a=9.9418(5) \AA$, $c=3.8832(2) \AA, Z=1)$ were prepared by reaction of the elements in an electric arc furnace and subsequent annealing. The crystal structures were solved and refined from single crystal diffraction data. $\mathrm{ScPt}_{2} \mathrm{Si}$ crystallizes with an 'inverse' $\mathrm{MgCuAl}_{2}$ structure while $\mathrm{Sc}_{5} \mathrm{Pt}_{9} \mathrm{Si}_{7}$ forms a variant of the $\mathrm{Zr}_{2} \mathrm{Fe}_{12} \mathrm{P}_{7}$ type.
\end{abstract}

\footnotetext{
* Prof. Dr. Walter Jung, Institut für Anorganische Chemie, Universität zu Köln, Greinstr. 6, D-50939 Köln Fax: +49 (0)221 4705083

E-mail: walter.jung@uni-koeln.de
}

\section{Introduction}

While ternary silicides of the platinum metals with a havier rare earth metal (Y, La-Lu) as a third component have been studied to a larger extent [1], less is known about corresponding compounds with scandium. Former phase analytical work done by Braun et al. [2] in the system Sc$\mathrm{Rh}-\mathrm{Si}$ revealed the existence of 9 ternary phases. However, later on only $\mathrm{ScRhSi}$ [3], $\mathrm{ScRhSi}_{2}$ [4], $\mathrm{ScRh}_{3} \mathrm{Si}_{7}$ [5] and $\mathrm{Sc}_{5} \mathrm{Rh}_{4} \mathrm{Si}_{10}$ [6] were structurally characterized, the latter only from powder data. Four ternary phases have been reported in the System Sc-Ir-Si, but only the structures of $\mathrm{ScIr}_{3} \mathrm{Si}_{7}$ [5] and $\mathrm{Sc}_{5} \mathrm{Ir}_{4} \mathrm{Si}_{10}$ [6] are known from single crystal work. The structures of ScIrSi [3] and $\mathrm{Sc}_{4} \mathrm{Ir}_{7} \mathrm{Si}_{6}$ [7] were assigned on the basis of powder patterns. This holds also for the structures of ScPdSi and ScRuSi [3]. The structure of $\mathrm{Sc}_{3} \mathrm{Os}_{2} \mathrm{Si}_{6}$ is not yet known [6]. In the system Sc-Pt-Si for a long time only $\mathrm{ScPtSi}$ with TiNiSi type structure was known [3], until recently $\mathrm{Sc}_{3} \mathrm{PtSi}_{3}$ together with $\mathrm{Sc}_{2} \mathrm{RuSi}_{2}$ was presented by Harmening et al. at a conference [8]. Here we report on $\mathrm{ScPt}_{2} \mathrm{Si}$ and $\mathrm{Sc}_{5} \mathrm{Pt}_{9} \mathrm{Si}_{7}$ crystallizing with variants of the $\mathrm{MgCuAl}_{2}$ [9] and the $\mathrm{Zr}_{2} \mathrm{Fe}_{12} \mathrm{P}_{7}$ type [10], respectively.

\section{Results and Discussion}

$\mathrm{ScPt}_{2} \mathrm{Si}$

$\mathrm{ScPt}_{2} \mathrm{Si}$ crystallizes in space group $\mathrm{Cmcm}$ and may be formally assigned to the $\mathrm{MgCuAl}_{2}$ type of structure [9], an ordered variant of the $\operatorname{Re}_{3} \mathrm{~B}$ type [11]. This structure type is frequently observed, especially with alkaline earth or rare earth transition metal gallides, indides, and stannides like $\mathrm{CaPtGa}_{2}$ [12], $\mathrm{CePdIn}_{2}$ [13], or $\mathrm{EuIrSn}_{2}$ [14]. In these compounds transition metal and post-transition metal atoms occupy the sitesets $4 c$ and $8 f$, respectively. In $\mathrm{ScPt}_{2} \mathrm{Si}$, however, these sitesets are interchanged. Platinum atoms are now the majority component and reside on $8 f$, while silicon atoms are found on $4 c$. Therefore, the $\mathrm{ScPt}_{2} \mathrm{Si}$ structure may be called an 'inverse' $\mathrm{MgCuAl}_{2}$ type.

The $\mathrm{MgCuAl}_{2}$ structure has been described in a somewhat formal way [13], aiming at rows of trigonal prisms running along the a axis and shifted against each other by $a / 2$. In the case of $\mathrm{ScPt}_{2} \mathrm{Si}$ the prisms are formed by platinum and scandium atoms and they are centered by silicon atoms. In Figure 1a, a projection of the structure along [100], these prisms are emphasized by bold lines. In Figure $1 \mathrm{~b}$ they are compared to corresponding prisms in the structure of 
$\mathrm{CaPtGa}_{2}$. This view of the structure originates from the archetype $\operatorname{Re}_{3} \mathrm{~B}$, because trigonal transition metal prisms centered by boron atoms are typical building elements of metal rich borides. To $\mathrm{ScPt}_{2} \mathrm{Si}$ a different description is more adequate. According to the differences between the electronegativities of scandium on one side and platinum and silicon on the other side, the commonly accepted bonding model regards positively charged scandium atoms and a polyanion built of platinum and silicon atoms. In Figure 2 showing perspective views of the structure, this polyanion is emphasized by drawing $\mathrm{Pt}-\mathrm{Pt}$ and $\mathrm{Pt}-\mathrm{Si}$ bonds. It contains channels with pentagonal and with hexagonal cross sections running along the $\mathrm{a}^{-}$and the c-axis, respectively. The scandium atoms are located at the points of intersection inside of these channels. Their environment is shown in Figure 3a. It consists of three silicon atoms

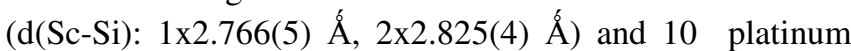

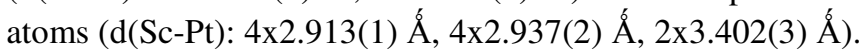
From the latter only 8 are close enough for bonding interactions. Their distances correspond to the sum of the metallic radii for coordination number $(\mathrm{CN}) 12$ [15]. The silicon atoms are surrounded by 6 platinum atoms $(\mathrm{d}(\mathrm{Si}-\mathrm{Pt})$ : 2x2.430(2) Á, 4x2.496(2) Á) forming a distorted trigonal prism and three scandium atoms capping the side-faces of the prism (Figure $3 \mathrm{~b}$ ). The coordination polyhedron around the platinum atom is quite irregular. It is built up by four scandium, four platinum, and three silicon atoms. The shortest interatomic distances in the structure are those between platinum and silicon atoms with a mean value of $2.474 \AA$ which is nearly the same as the sum of Pauling's single bond radii for platinum and silicon of $2.468 \AA$ [15]. Strong bonding interactions may thus be assumed, supporting the model of a Pt-Si-polyanion. All the interatomic distances considered above compare well with those found in ScPtSi [3].

$\mathrm{ScPt}_{2} \mathrm{Si}$ is the first silicide crystallizing with an ordered variant of the $\operatorname{Re}_{3} \mathrm{~B}$ type. The structure of $\mathrm{Re}_{3} \mathrm{~B}$ is closely related to that of $\mathrm{Fe}_{3} \mathrm{C}$ [16]. An ordered variant of the latter is already known with the $\mathrm{YPd}_{2} \mathrm{Si}$ structure adopted by two series of ternary rare earth silicides of palladium and platinum [17]. Therefore the existence of a ternary silicide with $\operatorname{Re}_{3} \mathrm{~B}$ derived structure was formerly predicted by Parthé and Chabot [1b].

$\mathrm{Sc}_{5} \mathrm{Pt}_{9} \mathrm{Si}_{7}$

The crystal structure of $\mathrm{Sc}_{5} \mathrm{Pt}_{9} \mathrm{Si}_{7}$, shown as a projection along the c-axis in Figure 4, is a substitution variant of the $\mathrm{Zr}_{2} \mathrm{Fe}_{12} \mathrm{P}_{7}$ structure [10], a well known structure type, which is adopted by numerous ternary transition metal phosphides preferently with a rare earth metal as the third component. $\mathrm{Sc}_{5} \mathrm{Pt}_{9} \mathrm{Si}_{7}$ and $\mathrm{Zr}_{2} \mathrm{Fe}_{12} \mathrm{P}_{7}$ both crystallize in space group $P \overline{6}$ with similar lattice constants and positional parameters. The phosphorus positions are taken by the silicon atoms. Three of the four iron sitesets $(2 \times 3 j+3 k)$ are occupied by platinum atoms, while the remaining one $(3 k)$ is occupied by scandium atoms. The other scandium atoms reside on the zirconium positions. $\mathrm{Sc}_{5} \mathrm{Pt}_{9} \mathrm{Si}_{7}$ is not the first compound, in which a substitution of transition metal atoms on this special $3 \mathrm{k}$ site by the more electropositive component is observed, but it is the first example of a complete substitution, and it is the first silicide with a $\mathrm{Zr}_{2} \mathrm{Fe}_{12} \mathrm{P}_{7}$ derivative structure. Examples of substitution to a small extent are the compounds $\mathrm{Mg}_{2.5} \mathrm{Ni}_{11.5} \mathrm{P}_{7}, \mathrm{Ca}_{2.1} \mathrm{Ni}_{11.9} \mathrm{P}_{7}$, and $\mathrm{Ca}_{2.3} \mathrm{Ni}_{11.7} \mathrm{As}_{7}$ [18], while in $\mathrm{Yb}_{2+3-\mathrm{x}} \mathrm{Pd}_{12-3+\mathrm{x}} \mathrm{P}_{7}$ with $(\mathrm{x}=0.40)$ the substitution is nearly complete [19]. With regard to these examples, a statistical distribution of scandium and platinum atoms on the $3 \mathrm{k}$ site of $\mathrm{Sc}_{5} \mathrm{Pt}_{9} \mathrm{Si}_{7}$ could also be possible. However, in samples with different compositions no significant deviations of the lattice parameters were observed. Therefore a constant composition is assumed.

As stated above for $\mathrm{ScPt}_{2} \mathrm{Si}$, the structure of $\mathrm{Sc}_{5} \mathrm{Pt}_{9} \mathrm{Si}_{7}$ is best discussed considering a 3D-polyanion built from platinum and silicon atoms in which positively charged scandium atoms are inserted (Figure 4). This view is again supported by the short distances between platinum and silicon atoms (Table 4) indicating strong bonding interactions. The three kinds of platinum atoms are tetrahedrally coordinated by four silicon atoms. The Pt-Si distances range from 2.336(6) to 2.761(5) Á with a mean value of $2.486 \AA$ which again is nearly equal to the sum of Pauling's single bond radii [15]. Moreover three platinum atoms (d(Pt-Pt): 2.815(1) $\AA-2.900(1) \AA ̊$ ) and four scandium atoms (d(Pt-Sc): 2.913(4) $\AA$ - 3.402(1) $\AA$ ) contribute to the first coordination spheres of the platinum atoms. The silicon atoms $\mathrm{Si} 1, \mathrm{Si} 2$, and $\mathrm{Si} 3$ are connected to three, five, and six platinum atoms, respectively.

The three crystallographically distinct scandium atoms are located in channels with pentagonal and hexagonal crosssections running in the direction of the c-axis (Figure 4). Their environments are shown in Figure 5. The pentagonal channels containing the $\mathrm{Sc} 1$ atoms are arranged in groups of three. This results in a clustering of the Sc1 atoms (Figure 5a) and Sc1-Sc1 distances of 3.396(8) Á, which are the shortest distances between scandium atoms in the structure. They are, however, still larger than those observed in $h c p$ scandium (3.254 and $3.309 \AA$ \& [20]). All other Sc-Sc distances are larger than $3.78 \AA$ indicating the absence of bonding interactions. Depending on the cross-sections of the channels, the first coordination spheres of the scandium atoms are either pentagonal or hexagonal prisms. They are completed by additional atoms in front of the rectangular side-faces. The prisms, highlighted by bold lines in Figure 5, are composed of six platinum and four silicon atoms in the case of Sc1 and of six platinum and six silicon atoms in the case of $\mathrm{Sc} 2$ and $\mathrm{Sc} 3$. Atoms capping the side-faces are $1 \mathrm{Pt}+1 \mathrm{Si}$ for $\mathrm{Sc} 1,3 \mathrm{Pt}$ for $\mathrm{Sc} 2$, and $6 \mathrm{Pt}$ for $\mathrm{Sc} 3$. The $\mathrm{Sc}-\mathrm{Pt}$ distances range from 2.913(4) to 3.200(1) Á, the Sc-Si 
distances from $2.759(3)$ to $2.990(5) \AA$. The former are thus close to, the latter smaller than the sum of the metallic radii for CN 12 [15].

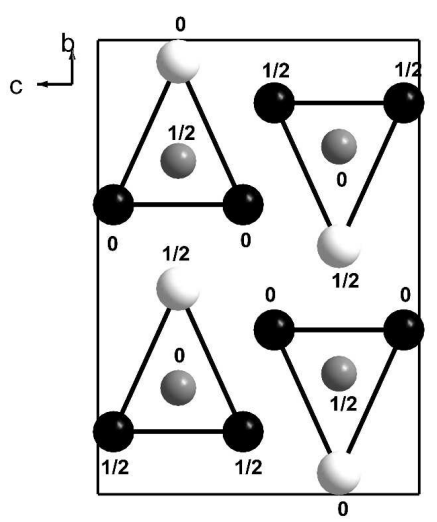

a

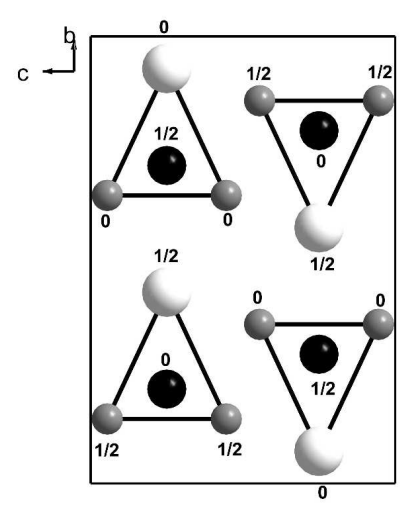

b
Figure 1. Projections along [100] of the structures of a) $\mathrm{ScPt}_{2} \mathrm{Si}$ ('inverse' $\mathrm{MgCuAl}_{2}$ type) and b) $\mathrm{CaPtGa}_{2}\left(\mathrm{MgCuAl}_{2}\right.$ type $(\mathrm{Pt}$ : black; Si, Ga: gray; Sc, Ca: white; this holds for all drawings; numbers indicate $\mathrm{x}$ parameters of the atoms; unit cells outlined). The lines emphasizing the trigonal prisms do not all represent chemical bonds.
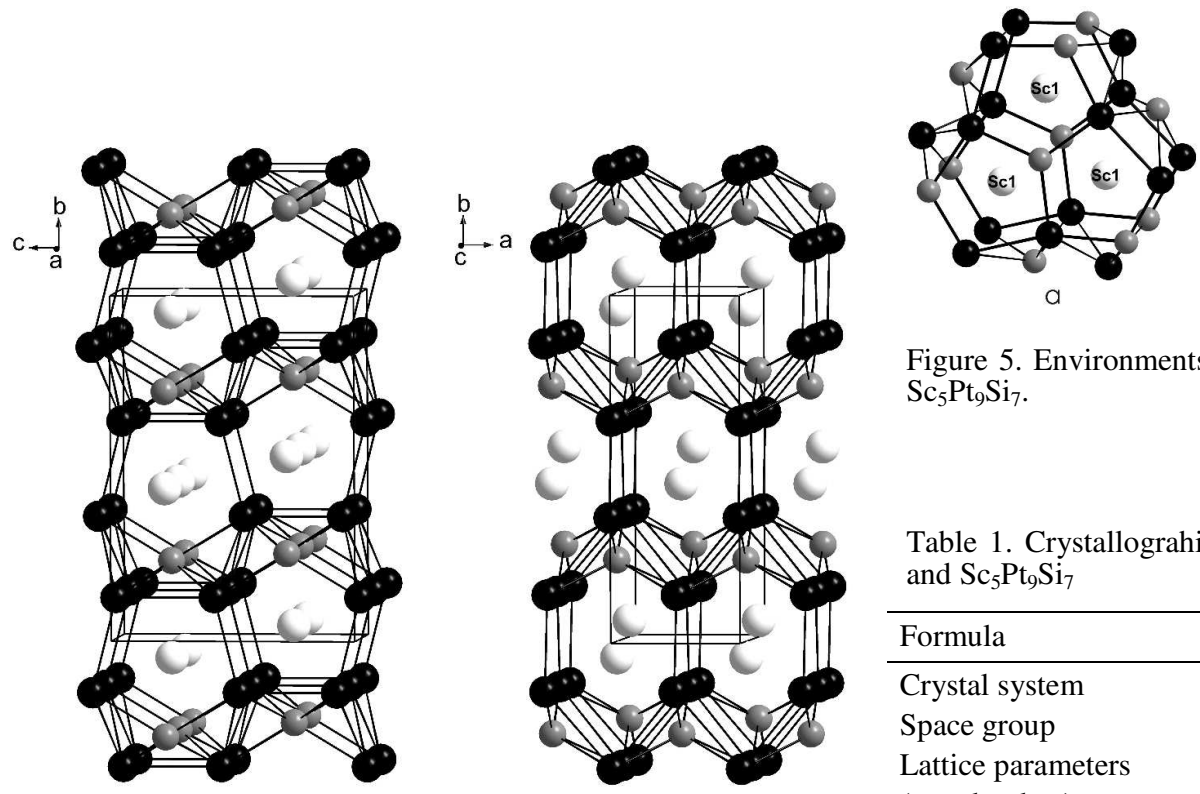

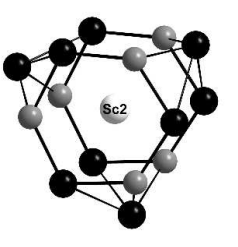

b

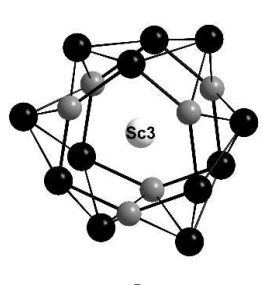

C
Figure 5. Environments of the scandium atoms in the structure of $\mathrm{Sc}_{5} \mathrm{Pt}_{9} \mathrm{Si}_{7}$.

Table 1. Crystallograhic data and structure refinement of $\mathrm{ScPt}_{2} \mathrm{Si}$ and $\mathrm{Sc}_{5} \mathrm{Pt}_{9} \mathrm{Si}_{7}$

\begin{tabular}{lll}
\hline Formula & $\mathrm{ScPt}_{2} \mathrm{Si}$ & $\mathrm{Sc}_{5} \mathrm{Pt}_{9} \mathrm{Si}_{7}$ \\
\hline Crystal system & orthorhombic & hexagonal \\
Space group & $\mathrm{Cmcm}$ & $P \overline{6}$ \\
Lattice parameters & $a=3.665(6) \AA$ & $a=9.9418(5) \AA$ \\
(powder data) & $b=9.831(1) \AA$ & $c=3.8832(2) \AA$ \\
& $c=6.967(1) \AA$ & \\
& $V=251.05 \AA^{3}$ & $V=332.39 \AA^{3}$ \\
Fomula units/cell, $Z$ & \multicolumn{1}{c}{4} & \multicolumn{1}{c}{1} \\
Calculated density & $12.256 \mathrm{~g}^{3} \mathrm{~cm}^{3}$ & $10.877 \mathrm{~g} / \mathrm{cm}^{3}$ \\
Absorption coefficient & $113.9 \mathrm{~mm}^{-1}$ & $97.23 \mathrm{~mm}^{-1}$ \\
Crystal size & $20 \times 40 \times 50 \mu \mathrm{m}^{3}$ & $30 \times 40 \mathrm{x} 50 \mu \mathrm{m}^{3}$ \\
Transmission ratio (max/min) & 2.72 & 4.31 \\
Diffractometer & $\mathrm{STOE} \mathrm{IPDS}$ & $\mathrm{STOE} \mathrm{IPDS}$ \\
Radiation & $\mathrm{MoK} \alpha$ & $\mathrm{MoK} \alpha$ \\
$\varphi$ Range, increment & $0-200^{\circ}, 2.0^{\circ}$ & $0-200^{\circ}, 2.0^{\circ}$ \\
Exposure time & $9 \mathrm{~min}$ & $10 \mathrm{~min}$ \\
$\theta_{\text {max }}$ for data collection & $33^{\circ}$ & $33^{\circ}$ \\
Ranges for $h, k, l$ & $\pm 5, \pm 13, \pm 10$ & $\pm 15, \pm 15, \pm 5$ \\
Reflections measured & 1805 & 4787 \\
$\quad$ unique & 281 & 922 \\
$\quad I>2 \sigma(I)$ & 258 & 829 \\
$R_{\text {int }}$ & 0.0566 & 0.1165
\end{tabular}

Figure 2. Perspektive views of the $\mathrm{ScPt}_{2} \mathrm{Si}$ structure approximately along [100] and [001].

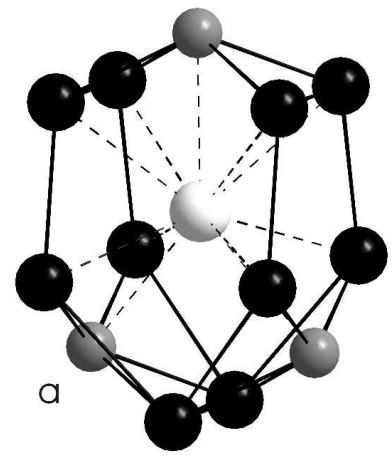

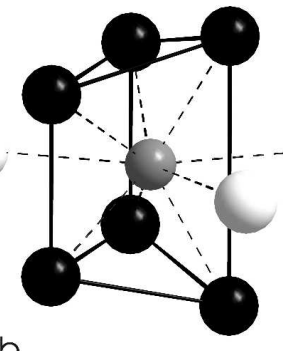

$\mathrm{b}$
Figure 3. Environments of a) Sc- and b) Si-atoms in the structure of

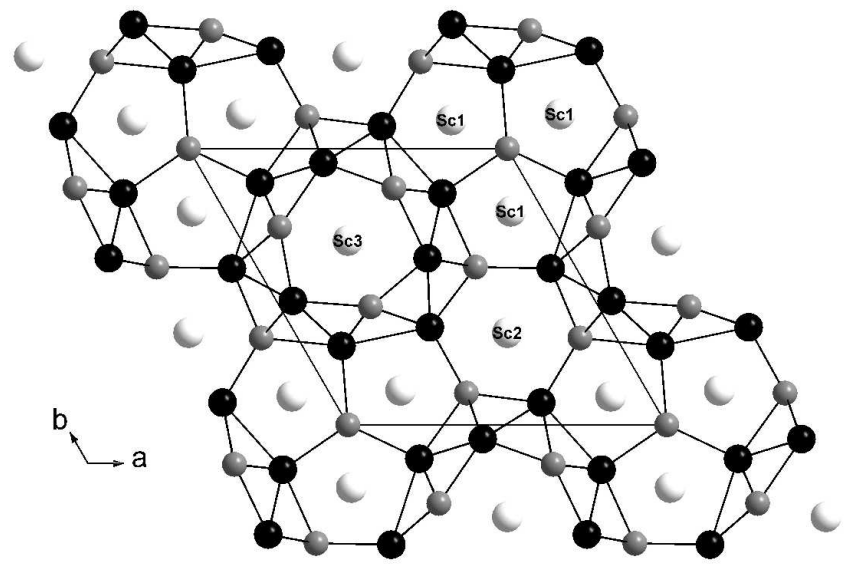

Figure 4. Projection of the $\mathrm{Sc}_{5} \mathrm{Pt}_{9} \mathrm{Si}_{7}$ structure along [001].

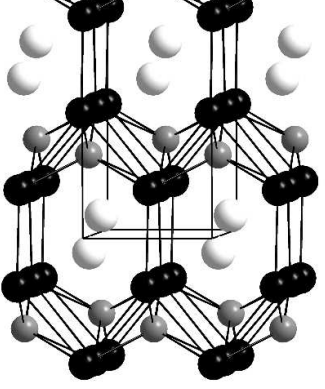

$R_{\text {in }}$ 
醇

wR2 efined parameters

Goodness-of-fit

Extinction coefficient

Flack parameter

Max/min residual density

$\begin{array}{ll}0.0289 & 0.0631 \\ 16 & 44 \\ 0.0255 & 0.0381 \\ 0.0543 & 0.0840 \\ 1.126 & 1.094 \\ 0.0030(3) & 0.0025(3) \\ - & 0.01(3) \\ 3.14 /-2.65 \mathrm{e} / \AA^{3} & 3.98 /-3.34 \mathrm{e} / \AA^{3}\end{array}$

Table 2. Atomic coordinates and equivalent isotropic displacement parameters $\left(\mathrm{pm}^{2}\right)$ for $\mathrm{ScPt}_{2} \mathrm{Si}$ (space group $\mathrm{Cmcm}$ ) and $\mathrm{Sc}_{5} \mathrm{Pt}_{9} \mathrm{Si}_{7}$ (space group $P \overline{6}$ ). $U_{\text {eq }}$ is defined as one third of the trace of the orthogonalized $U_{\mathrm{ij}}$ tensor.

\begin{tabular}{llllll}
\hline Atom & $\begin{array}{l}\text { Wykoff } \\
\text { position }\end{array}$ & $y$ & $z$ & $U_{\text {eq }}$ \\
\hline ScPt $_{2} S i:$ & & & & & \\
$\mathrm{Sc}$ & $4 c$ & 0 & $0.0469(3)$ & $1 / 4$ & $64(6)$ \\
$\mathrm{Pt}$ & $8 f$ & 0 & $0.36214(4)$ & $0.04860(6)$ & $62(2)$ \\
$\mathrm{Si}$ & $4 c$ & 0 & $0.7656(4)$ & $1 / 4$ & $58(8)$ \\
& & & & & \\
$\mathrm{Sc}_{5} \mathrm{Pt}_{9} \mathrm{Si}_{7}$ : & & & & & \\
$\mathrm{Sc} 1$ & $3 k$ & $0.2274(5)$ & $0.1244(6)$ & $1 / 2$ & $76(7)$ \\
$\mathrm{Sc} 2$ & $1 f$ & $2 / 3$ & $1 / 3$ & $1 / 2$ & $85(14)$ \\
$\mathrm{Sc} 3$ & $1 c$ & $1 / 3$ & 23 & 0 & $107(23)$ \\
$\mathrm{Pt} 1$ & $3 j$ & $0.1229(1)$ & $0.2854(1)$ & 0 & $68(2)$ \\
$\mathrm{Pt} 2$ & $3 j$ & $0.4338(1)$ & $0.3531(1)$ & 0 & $77(2)$ \\
$\mathrm{Pt} 3$ & $3 k$ & $0.0517(1)$ & $0.4487(1)$ & $1 / 2$ & $71(2)$ \\
$\mathrm{Si} 1$ & $1 a$ & 0 & 0 & 0 & $76(7)$ \\
$\mathrm{Si} 2$ & $3 j$ & $0.4298(1)$ & $01148(7)$ & 0 & $47(11)$ \\
$\mathrm{Si} 3$ & $3 k$ & $0.2844(7)$ & $0.4275(8)$ & $1 / 2$ & $58(12)$
\end{tabular}

Table 3. Anisotropic displacement parameters $\left(\mathrm{pm}^{2}\right)$ for $\mathrm{ScPt}_{2} \mathrm{Si}$ and $\mathrm{Sc}_{5} \mathrm{Pt}_{9} \mathrm{Si}_{7}$.

\begin{tabular}{lllllll}
\hline Atom & Site & $\mathrm{U}_{11}$ & $\mathrm{U}_{22}$ & $\mathrm{U}_{33}$ & $\mathrm{U}_{23}$ & $\mathrm{U}_{12}$ \\
\hline $\mathrm{ScPt}_{2} S i$ & & & & & & \\
$\mathrm{Sc}$ & $4 c$ & $48(11)$ & $30(11)$ & $112(15$ & 0 & 0 \\
$\mathrm{Pt}$ & $8 f$ & $81(2)$ & $46(2)$ & $57(3)$ & $-2(1)$ & 0 \\
$\mathrm{Si}$ & $4 c$ & $82(1)$ & $36(17)$ & $54(21)$ & 0 & 0 \\
$\mathrm{Sc}_{5} P t_{9} S i_{7}$ & & & & & & \\
$\mathrm{Sc} 1$ & $3 k$ & $43(18)$ & $114(20)$ & $60(19)$ & 0 & $32(16)$ \\
$\mathrm{Sc} 2$ & $1 f$ & $99(21)$ & $\mathrm{U}_{11}$ & $56(35)$ & 0 & $49(10)$ \\
$\mathrm{Sc} 3$ & $1 c$ & $101(23)$ & $\mathrm{U}_{11}$ & $127(40)$ & 0 & $51(12)$ \\
$\mathrm{Pt} 1$ & $3 j$ & $68(4)$ & $73(4)$ & $63(4)$ & 0 & $35(3)$ \\
$\mathrm{Pt} 2$ & $3 j$ & $54(4)$ & $67(4)$ & $100(4)$ & 0 & $23(3)$ \\
$\mathrm{Pt} 3$ & $3 k$ & $87(4)$ & $73(4)$ & $60(4)$ & 0 & $46(4)$ \\
$\mathrm{Si} 1$ & $1 a$ & $85(33)$ & $\mathrm{U}_{11}$ & $151(60)$ & 0 & $42(17)$ \\
$\mathrm{Si} 2$ & $3 j$ & $37(25)$ & $19(24)$ & $70(30)$ & 0 & $3(21)$ \\
$\mathrm{Si} 3$ & $3 k$ & $47(26)$ & $65(29)$ & $49(30)$ & 0 & $19(24)$ \\
& & & & & &
\end{tabular}

Table 4. Selected interatomic distances (A) for $\mathrm{ScPt}_{2} \mathrm{Si}$ and $\mathrm{Sc}_{5} \mathrm{Pt}_{9} \mathrm{Si}_{7}$

\begin{tabular}{rrrl}
\hline Atoms & $d$ & Atoms & $d$ \\
\hline$S c P t_{2} S i$ & & & \\
$\mathrm{Sc}-1 \mathrm{Si}$ & $2.766(5)$ & $\mathrm{Pt}-1 \mathrm{Si}$ & $2.430(2)$ \\
$2 \mathrm{Si}$ & $2.825(4)$ & $2 \mathrm{Si}$ & $2.496(2)$ \\
$4 \mathrm{Pt}$ & $2.913(1)$ & $1 \mathrm{Pt}$ & $2.794(1)$ \\
$4 \mathrm{Pt}$ & $2.937(2)$ & $1 \mathrm{Pt}$ & $2.806(1)$ \\
$\mathrm{Si}-2 \mathrm{Pt}$ & $2.430(2)$ & $2 \mathrm{Sc}$ & $2.913(1)$ \\
$4 \mathrm{Pt}$ & $2.496(2)$ & $2 \mathrm{Sc}$ & $2.937(2)$ \\
$1 \mathrm{Sc}$ & $2.766(5)$ & $2 \mathrm{Pt}$ & $2.946(1)$ \\
$2 \mathrm{Sc}$ & $2.826(4)$ & & \\
$\mathrm{S} c_{5} P t_{9} S i_{7}$ & & & \\
$\mathrm{Sc} 1-2 \mathrm{Si} 1$ & $2.759(3)$ & $\mathrm{Pt} 3-1 \mathrm{Si} 3$ & $2.336(6)$ \\
$1 \mathrm{Si} 3$ & $2.774(9)$ & $1 \mathrm{Si} 3$ & $2.426(7)$ \\
$2 \mathrm{Si} 2$ & $2.827(6)$ & $2 \mathrm{Si} 2$ & $2.466(4)$ \\
$2 \mathrm{Pt} 2$ & $2.913(4)$ & $2 \mathrm{Pt} 1$ & $2.839(1)$ \\
$2 \mathrm{Pt} 1$ & $2.940(4)$ & $2 \mathrm{Pt} 2$ & $2.900(1)$ \\
$1 \mathrm{Pt} 3$ & $2.976(5)$ & $1 \mathrm{Sc} 1$ & $2.976(5)$ \\
$2 \mathrm{Pt} 1$ & $3.012(4)$ & $2 \mathrm{Sc} 3$ & $3.200(1)$ \\
$\mathrm{Sc} 2-6 \mathrm{Si} 2$ & $2.990(5)$ & $1 \mathrm{Sc} 2$ & $3.402(1)$ \\
$6 \mathrm{Pt} 2$ & $3.102(1)$ & $\mathrm{Si} 1-3 \mathrm{Pt} 1$ & $2.465(1)$ \\
$1 \mathrm{Pt} 3$ & $3.402(1)$ & $6 \mathrm{Sc} 1$ & $2.759(3)$ \\
$\mathrm{Sc} 3-6 \mathrm{Si} 3$ & $2.916(5)$ & $\mathrm{Si} 2-1 \mathrm{Pt} 2$ & $2.346(6)$ \\
$6 \mathrm{Pt} 3$ & $3.200(1)$ & $1 \mathrm{Pt} 2$ & $2.353(7)$ \\
$\mathrm{Pt} 1-2 \mathrm{Si} 3$ & $2.465(4)$ & $2 \mathrm{Pt} 3$ & $2.466(4)$ \\
$1 \mathrm{Si} 1$ & $2.465(1)$ & $1 \mathrm{Pt} 1$ & $2.520(6)$ \\
$1 \mathrm{Si} 2$ & $2.520(6)$ & $2 \mathrm{Sc} 1$ & $2.827(6)$ \\
$1 \mathrm{Pt} 2$ & $2.815(1)$ & $2 \mathrm{Sc} 2$ & $2.990(5)$ \\
$2 \mathrm{Pt} 3$ & $2.839(1)$ & $\mathrm{Si} 3-1 \mathrm{Pt} 3$ & $2.336(6)$ \\
$2 \mathrm{Sc} 1$ & $2.940(4)$ & $1 \mathrm{Pt} 3$ & $2.426(7)$ \\
$2 \mathrm{Sc} 1$ & $3.012(4)$ & $2 \mathrm{Pt} 1$ & $2.465(4)$ \\
$\mathrm{Pt} 2-1 \mathrm{Si} 2$ & $2.346(6)$ & $2 \mathrm{Pt} 2$ & $2.761(5)$ \\
$1 \mathrm{Si} 2$ & $2.353(7)$ & $1 \mathrm{Sc} 1$ & $2.774(9)$ \\
$2 \mathrm{Si} 3$ & $2.761(5)$ & $2 \mathrm{Sc} 3$ & $2.916(5)$ \\
$1 \mathrm{Pt} 1$ & $2.815(1)$ & & \\
$2 \mathrm{Pt} 3$ & $2.900(1)$ & & \\
$2 \mathrm{Sc} 1$ & $2.913(4)$ & & \\
$2 \mathrm{Sc} 2$ & $3.102(1)$ & &
\end{tabular}

\section{Experimental Section}

\section{Synthesis}

Starting materials for the preparation of the title compounds were the elements: scandium metal, cut into small pieces (99.9\% Johnson Matthey), platinum powder (99.9\%, Degussa), and silicon pieces (m8N, Johnson Matthey). Mixtures of the elements in the atomic ratios according to the formulas were pressed into pellets of about $700 \mathrm{mg}$ weight and arc melted under purified argon. To achieve homogeneity, the buttons were turned around and remelted two times. Weigt loss during the melting process was negligible. Subsequently the buttons were placed in alumina crucibles, sealed in silica tubes under argon atmosphere and annealed four days at $1200^{\circ} \mathrm{C}$. Finally they were cooled to room temperature at a rate of $20^{\circ} \mathrm{C} / \mathrm{h}$. From the crushed samples single crystals of irregular shape were isolated. They are stable to moist air for long periods of time. Semi-quantitative EDX measurements (Philips XL40 scanning electron microscope with EDAX detector) confirmed the compositions of the crystals as obtained from the structure analysis and excluded the presence of other elements. 


\section{$X$-ray diffraction and crystal structure}

X-ray powder data were taken with a Guinier diffractometer (Huber $\mathrm{G} 645, \mathrm{CuK} \alpha_{1}, \mathrm{Si}$ as external standard). For correct indexing of the patterns they were compared to theoretical ones calculated on the basis of the structure refinements. While $\mathrm{ScPt}_{2} \mathrm{Si}$ was single phase according to the accuracy of the method, the $\mathrm{Sc}_{5} \mathrm{Pt}_{9} \mathrm{Si}_{7}$ samples contained $\mathrm{ScPtSi}$ as a by-product.

The quality of the single crystals was checked by means of Laue photographs taken on a Buerger precession camera. Single crystal intensity data were collected at room temperature on a STADI-I diffractometer. Numerical absorption corrections were performed after optimizing the crystal faces with the program X-SHAPE [21]. The structures were solved by means of direct methods with SHELXS-97 [22] and refined on $F^{2}$ values using SHELXL-97 [23] with anisotropic displacement parameters for all atoms. No significant peaks were found in the difference Fourier syntheses. Crystallographic data and details of the data collection and the structure refinement are listed in Table 1. Table 2 contains the positional parameters and the equivalent isotropic displacement parameters, Table 3 the anisotropic displacement parameters. Selected interatomic distances are listed in Table 4.

Further details of the structure determinations may be obtained from: Fachinformationszentrum Karlsruhe, D-76344 EggensteinLeopoldshafen (Germany) by quoting the Registry No's. CSD$420355\left(\mathrm{ScPt}_{2} \mathrm{Si}\right)$ and $\mathrm{CSD}-420356\left(\mathrm{Sc}_{5} \mathrm{Pt}_{9} \mathrm{Si}_{7}\right)$.

\section{Acknowledgments}

Financial support by the Deutsche Forschungsgemeinschaft is gratefully acknowledged.

[1] a) P. Rogl in Handbook on the Physics and Chemistry of Rare Earths (Eds.: K. A. Gschneidner, Jr. and L. Eyring), North-Holland Physics Publishing, Amsterdam, New York, Oxford, Tokyo, 1984, Vol. 7; b) E. Parthé, B. Chabot in Handbook on the Physics and Chemistry of Rare Earths (Eds.: K. A. Gschneidner, Jr. and L. Eyring), North-Holland Physics Publishing, Amsterdam, New York, Oxford, Tokyo, 1984, Vol. 6.

[2] H. F. Braun, G. Burri, L. Rinderer, J. Less-Common Metals 1979, 68, P1-P8.

[3] E. Hovestreydt, N. Engel, K. Klepp, B. Chabot, E. Parthé, J. Less-Common Metals 1982, 85, 247-274.

[4] B. Chabot, H. F. Braun, K. Yvon, E. Parthé, Acta Crystallogr. 1981, B37, 668-671.

[5] B. Chabot, N. Engel, E. Parthé, Acta Crystallogr. 1981, B37, 671-673.

[6] H. F. Braun, C. U. Segre, Solid State Commun. 1980, 35, 735-738.

[7] N. Engel, B. Chabot, E. Parthé, J. Less-Common Metals. 1984, 96, 291-296.

[8] T. Harmening, R.-D. Hoffmann, H. Eckert, R. Pöttgen, Z. Anorg. Allg. Chem. 2008, 2043.

[9] H. Perlitz, A. Westgren, Ark. Kemi, Miner. Geol. 1943, 16B, 1.

[10] E. Ganglberger, Monatsh. Chem. 1968, 99, 557-865.

[11] B. Aronsson, M. Bäckmann, S. Rundqvist, Acta Chem. Scand. 1960, 14, 1001-1005.
[12] K. Dascoulidou-Gritner, H.-U. Schuster, Z. Naturforsch. 1993, $48 B, 844$.

[13] Y. Ijiri, F. J. DiSalvo, H. Yamane, J. Solid State Chem. 1996, 122, 143-147.

[14] R. Pöttgen, R. D. Hoffmann, M. H. Moeller, G. Kotzyba, B. Kuennen, C. Rosenhahn, B.D. Mosel, J. Solid State Chem. 1999, 145, 174-181.

[15] L. Pauling, Die Natur der Chemischen Bindung. Verlag Chemie, Weinheim, 1973.

[16] F. H. Herbstein, J. Smuts, Acta Crystallogr. 1964, 17, 1331.

[17] J. M. Moreau, J. L. Roy, D. Paccard, Acta Crystallogr. 1982, B38, 2446-2448.

[18] A. Mewis, Z. Naturforsch. 1980, 35, 620-625.

[19] S. Budnyk, Yu. Prots, M. Schmidt, W. Schnelle, Yu. Kuz'ma, Yu. Grin, Z. Anorg. Allg. Chem. 2004, 630, 1062-1067.

[20] F. H. Spedding, A. H. Daane, K. W. Herrmann, Acta Crystallogr. 1956, 9, 559-563.

[21] a) X-RED, Version 1.10, STOE Data Reduction Program, STOE \& Cie GmbH, Darmstadt, 1998; b) X-SHAPE, Version 1.06, Crystal Optimisation for Numerical Absorption Correction, STOE \& Cie GmbH, Darmstadt, 1999.

[22] G. M. Sheldrick, SHELXS-97 - Program for the Determination of Crystal Structures, University of Göttingen, Germany 1997.

[23] G. M. Sheldrick, SHELXL-97 - Program for Crystal Structure Refinement, University of Göttingen, Germany 1997.

Received: ((will be filled in by the editorial staff)) Published online: ((will be filled in by the editorial staff)) 

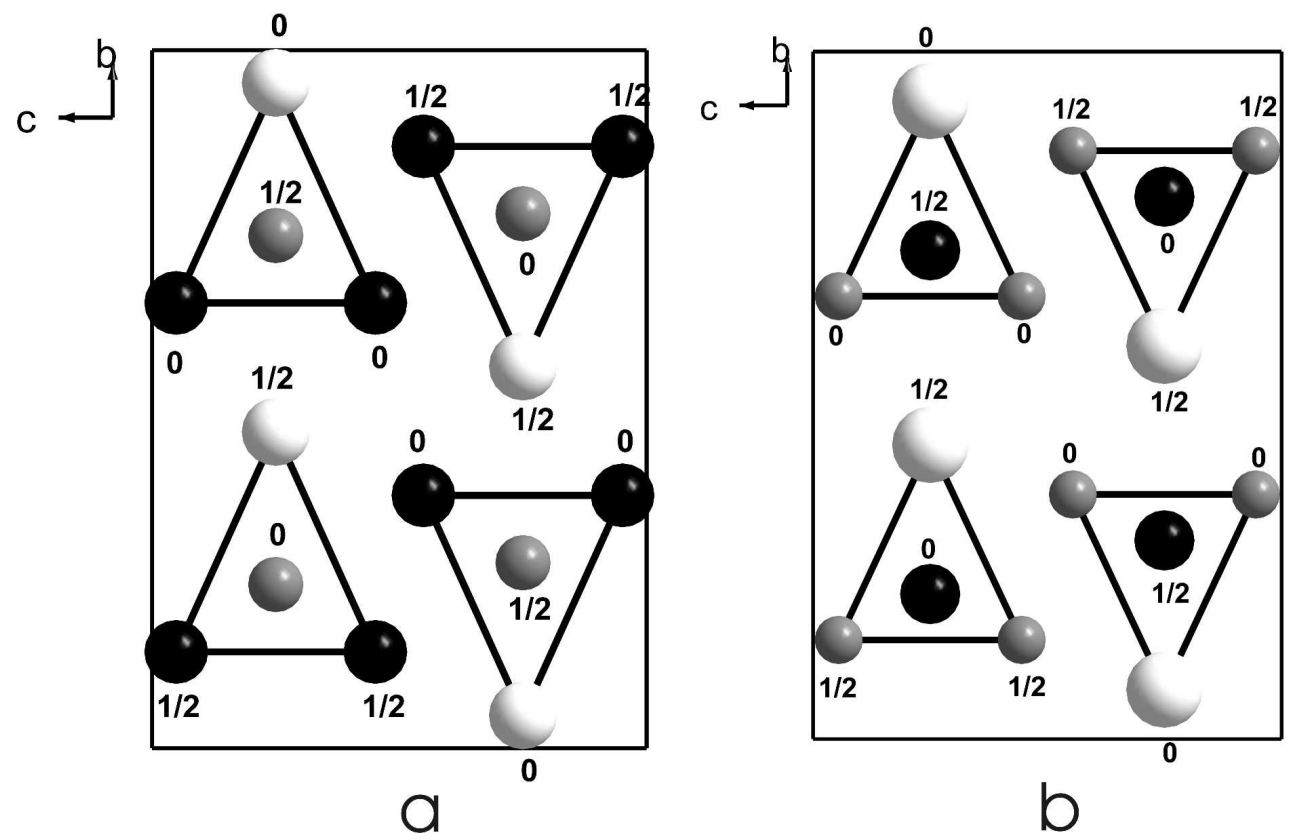

Figure 1. Projections along [100] of the structures of a) ScPt2Si ('inverse' MgCuAl2 type) and b) CaPtGa2 (MgCuAl2 type) (Pt: black; Si, Ga: gray; Sc, Ca: white; this holds for all drawings; numbers indicate $x$ parameters of the atoms; unit cells outlined). The lines emphasizing the trigonal prisms do not all represent chemical bonds. $162 \times 104 \mathrm{~mm}(600 \times 600 \mathrm{DPI})$ 

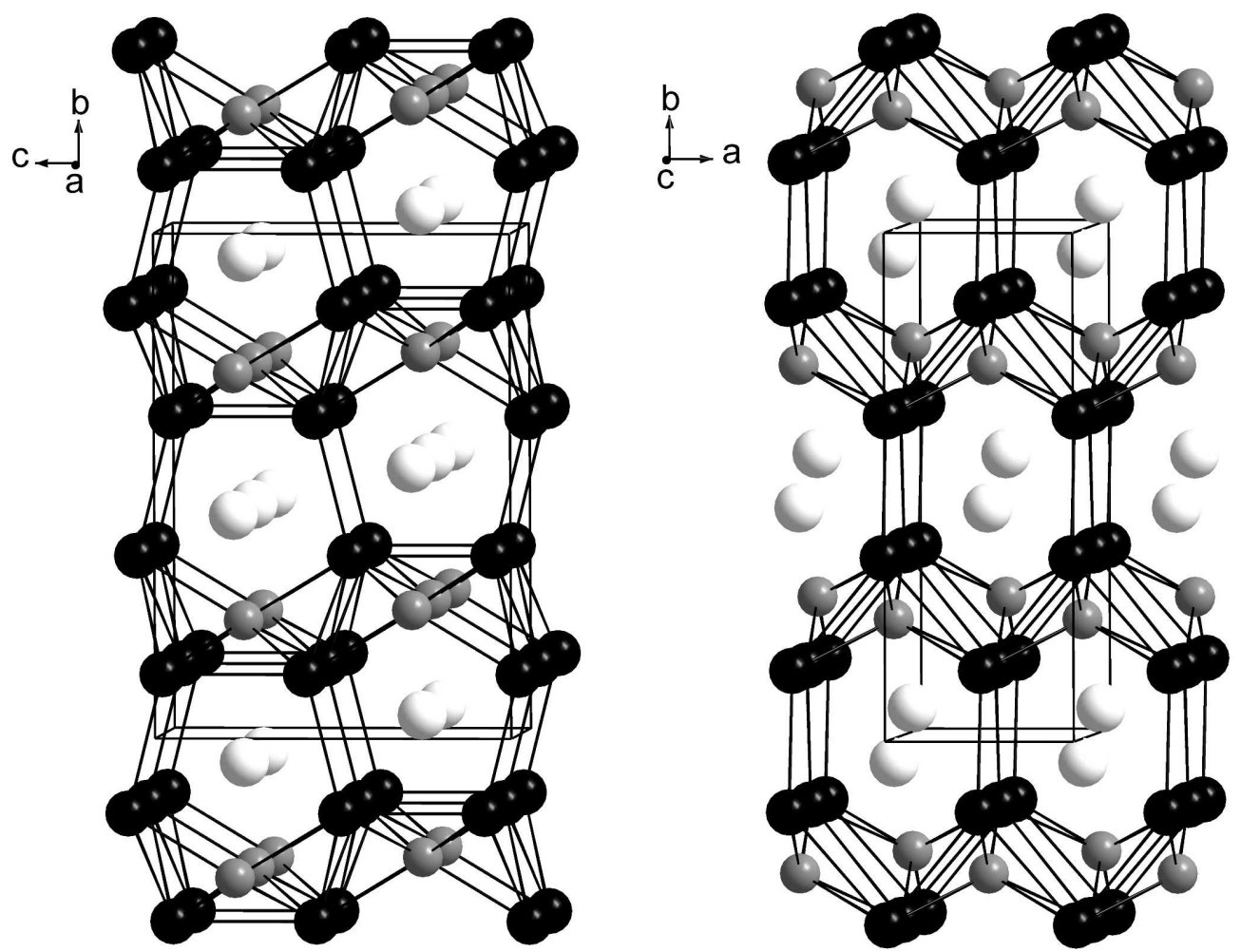

Figure 2. Perspektive views of the ScPt2Si structure approximately along [100] and [001]. $175 \times 137 \mathrm{~mm}(600 \times 600 \mathrm{DPI})$ 

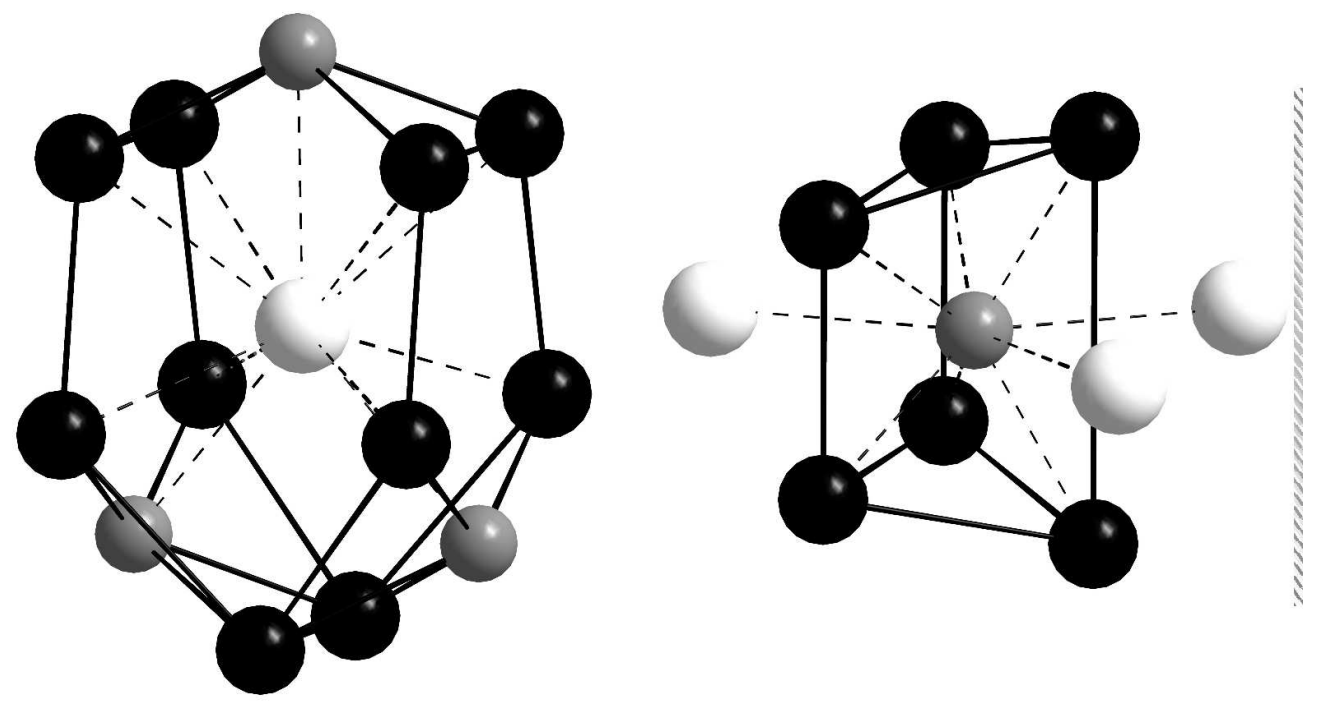

Figure 3. Environments of a) Sc- and b) Si-atoms in the structure of ScPt2Si. $201 \times 109 \mathrm{~mm}(600 \times 600 \mathrm{DPI})$ 


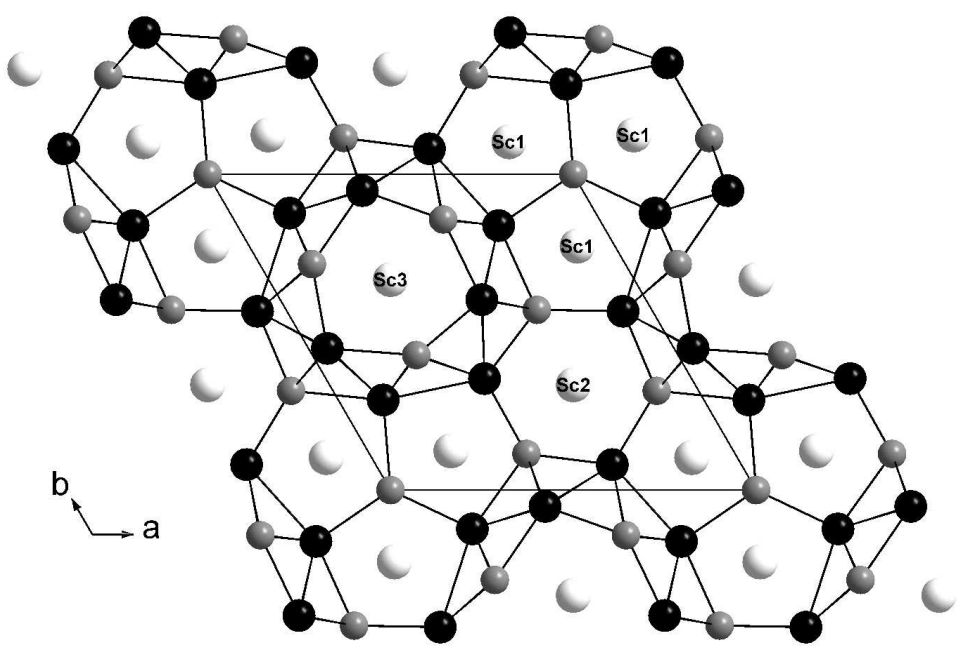

Figure 4. Projection of the Sc5Pt9Si7 structure along [001]. $1963 \times 1029 \mathrm{~mm}(96 \times 96 \mathrm{DPI})$ 


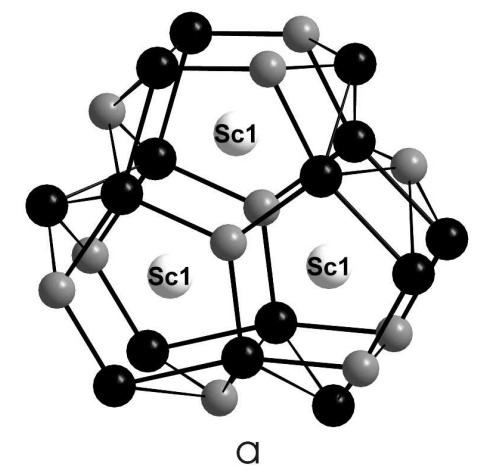

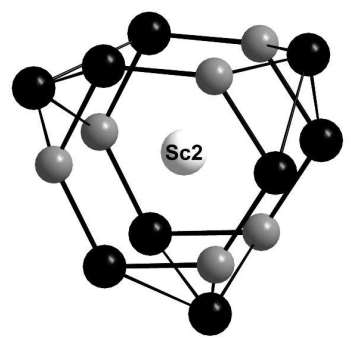

$b$

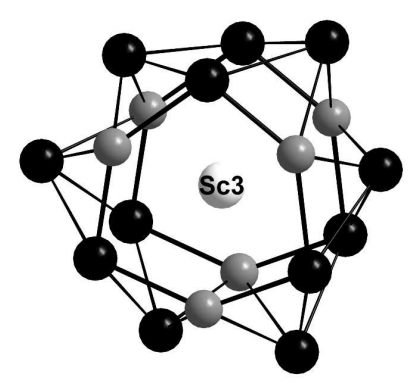

C

Figure 5. Environments of the scandium atoms in the structure of Sc5Pt9Si7 $184 \times 65 \mathrm{~mm}(600 \times 600 \mathrm{DPI})$ 